\title{
Pleckstrin Homology Domain-Containing Family G Member 5
}

National Cancer Institute

\section{Source}

National Cancer Institute. Pleckstrin Homology Domain-Containing Family G Member 5. NCI Thesaurus. Code C150303.

Pleckstrin homology domain-containing family G member 5 (1062 aa, $117 \mathrm{kDa}$ ) is encoded by the human PLEKHG5 gene. This protein plays a role in the activation of transforming protein RhoA and nuclear factor kappa B signaling pathways. 